\title{
THE SPATIAL STRUCTURE OF GRAY FOREST SOIL BACTERIAL CENOSIS UNDER DIFFERENT CONDITIONS OF USE
}

\section{M. Malynovska}

National Scientific Centre "Institute of Agriculture of the NAAS", Chabany urban-type settlement, Kyiv Region, Ukraine; e-mail: irina.malinovskaya.1960@mail.ru

Under the conditions of the stationary experiment (agrarian soils) and in the 22-year-old deposit areas, the state of microbiocenoses of individual horizons of gray forest soil: humusaccumulative $(0-29 \mathrm{~cm})$, illuvial $(30-50 \mathrm{~cm})$, transitional from illuvial horizon to solid $(92-110 \mathrm{~cm})$ was studied. It was established that the quantity and physiological and biochemical activity of the microorganisms of the studied ecological-trophic groups, the intensity and direction of the mineralization processes are changing by the soil profile. The nature and extent of such changes significantly depends on the way the soil is used.

Key words: bacterial cenoses, soil profile horizons, gray forest soil, ecological and trophic groups, mineralization.

The efforts of microbiologists are traditionally aimed at studying the microbial cenosis of the arable layer of soil, where the main stocks of organic matter are concentrated and microbiological processes are more intensive. Usually poor organic matter lower horizons, transitional between the humus layer and litter rocks are less studied. However, the population level of microorganisms in the middle and lower horizons has both theoretical and practical interest.

L. M. Polianska et al. [1] on the example of four zonal soil types (gray forest, soddypodzolic, black and chestnut), it was established that the biomass of soil microorganisms is relatively evenly distributed along the entire profile, rather than concentrated mainly in surface horizons. For peat soils, data has also been obtained about the uniform distribution of microbial biomass in many meter thickness [2].

Studies in which the microbial population of the soil profile was evaluated mainly related to the determination of the number of microorganisms in individual groups $[3,4]$ or the total number of bacterial cells and biomass of micromycetes $[2,5]$. At the same time, the state of microbial cenosis of separate horizons of the soil as integral structures was not studied, direction and intensity of mineralization processes depending on the depth in the soil was not evaluated. The objective of our study was to study the structure of bacterial cenosis of separate horizons of gray forest soils of various uses. 
Materials and methods. The study was carried out on gray forest soil (experimental farm "Chabany" of Kyivo-Sviatoshynskyi district of the Region of Kyiv) in territorially close areas: 1 soil removed from agricultural use in 1987; 2-3 - agrarian soils of the stationary experiment, which was laid in 1987. The studied variants with the system of soil cultivation traditional for the ForestSteppe zone, with integrated pest, disease and weed protection and agrochemical loading of various intensity were studied: 2 - control, field crop rotation without the use of mineral and organic fertilizers (extensive agrarian soil); 3 - field crop rotation with mineral fertilizers ${ }_{N_{96}} \mathrm{P}_{108} \mathrm{~K}_{112.5}$ at the background of plowing a crop production by-product (intense agrarian soil).

The selection of soil samples was carried out from the horizons: He -humus-accumulative $(0-29 \mathrm{~cm})$, Ih - illuvial $(30-50 \mathrm{~cm}), \mathrm{Pi}$ - transitional from the illuvial horizon to the solid (92$110 \mathrm{~cm})[6]$.

The number of microorganisms of certain ecological trophic groups was estimated by the method of seeding a soil suspension on the appropriate digestive media [7]. The intensity of the mineralization of nitrogen compounds was calculated according to E. N. Mishustin and E. V. Runov [8], pedotrophicity coefficient - according to D. I. Nikitin and V. S. Nikitina [9], humus mineralization process activity - by I. S. Demkina and B. N. Zolotariova [10].

The number of microorganism colonies was counted for 21 days, depending on the growth rate and physiological characteristics of microorganisms of certain ecological trophic groups. Probability of bacterial colonies formation (BCF) was determined by S. Ishikuri and T Hattori method, described by P. A. Kozhevin et al. [11].

Results and discussion. According to Table 1, the soil of the horizon Ih contains much less microorganisms than the horizon He. Thus, the number of ammonifiers is reduced by 24.0 times in the Ih horizons of laylands, extensive agrarian soil - by 38.5 times, intensive agrarian soil - by 47.0 times. Similar indicators for pedotrophs are decreased by 28.6, 29.6 and 30.9 times, for cellulosolytics - by 28.0, 22.4 and 22.3, for polysaccharide-synthesizing microorganisms - by 42.0 , 23.7 and 5.5 times. respectively. The obtained data partly confirm the results of L. M. Polianska et al. [1], which found that $20-40 \mathrm{~cm}$ layer of gray forest soil contains only 23 times less microorganisms than in the horizon $0-20 \mathrm{~cm}$. However, according to the same authors, with the further deepening of the profile, the number of microorganisms almost does not change. Similar data on the total number of microorganisms by the same authors were also obtained for typical black soil. The results of our studies indicate a sharp decrease in the number of microorganisms with deepening to the horizon Pi: ammonifiers in the layland soil - by 4,500 times, extensive agrarian soil - by 9,800 times, intensive agrarian soil - by 9,700 times compared with He horizon. Corresponding indices for polysaccharide-synthesizing bacteria are decreased by 19,100, 13,200 and 8,700 times, for micromycetes - by 385, 898 and 198 times. Perhaps this difference in the results can be explained by the use of various methods for determining the number of 
microorganisms, in particular, the method of direct counting of microorganisms by luminescent microscopy, the disadvantage of which is the unreliability of differentiation of living and dead cells, which gives an overestimated result of calculations.

Distribution of microorganisms by the profiles of the studied variants of use of gray forest soil is significantly different. Thus, the layland soil of He horizon contains more microorganisms than in the soil of extensive and intensive agrocenoses: polysaccharide-synthesizing - by 3.0 and 5.6 times, pedotrophs - by 3.1 and 2.3, oligonitrophils - by 3.3 and 3.2 , denitrifiers - by 3.9 and 4.9, mineral phosphates mobilizers - by 2.8 and 3.5, organic phosphates mobilizers - by 5.1 and 3.8 , streptomycetes - by 2.2 and 1.6 times, respectively. The number of ammonifiers in layland He horizon exceeds the corresponding indicator of extensive agrocenosis by $79 \%$, and the soil of intensive agrarian soil contains $10.5 \%$ more ammonifiers than in the layland. A similar pattern is observed with regard to immobilizers of mineral nitrogen, which are used in the metabolism of ammonifiers products: the maximum amount of nitrogen immobilizers is contained in intensive agrarian soil - by $14.5 \%$ more than in the layland, and by 6.92 times more than in the extensive agrarian soil (Table 1).

Comparison of indicators of the layland Ih horizon with the extensive and intensive agrarian soils shows that the first contains more ammonifiers, pedotrophs, oligonitrophils, mineral nitrogen immobilizers, denitrifiers, mineral phosphate mobilizers, organic phosphates mobilizers, nitrifies, and streptomyces; layland $\mathrm{Pi}$ horizon contains more ammonifiers, pedotrophs, cellulolytics, oligonitrophils, mineral nitrogen immobilizers, and micromycetes (Table 1). This testifies to the existence of an effective substrate transport system down the profile to the lower horizons. Therefore, the number of microorganisms in the layland soil is decreasing in the depth of the profile not so intensively, as in agrarian soils. At the same time, there is a pattern: if the number of microorganisms of a certain group in the upper layland horizon is smaller than in agrarian soils then in the Pi horizon their number exceeds the corresponding index of agrarian soil.

In the layland soil the intensity of decrease in the number of cellulolytics is higher than the indicators of extensive and intensive agrocenoses - by 28.0 and 22.4 times, respectively. Perhaps this is due to the movement of soil in the process of plowing in agrocenoses, which contributes to the penetration of cellulose-containing substrates into deeper layers of soil. However, layland Pi horizon contains a larger number of cellulolytics than agrocenoses, and the rate of decline in number in the depth of the profile is minimal (5,000 times), in agrocenoses the rate of decrease in the number of cellulolytics is 13,500 and 23,100 times, respectively. Consequently, a sufficient amount of soluble cellulose derivatives, used by cellulolytics for growth, is transported through the capillary system of the layland soil to the depth of the profile. A similar pattern is observed regarding the number of ammonifiers, pedotrophs, micromycetes and microorganisms of other groups. 
Table 1 Number of microorganisms in the horizons of gray forest soils of various uses, $10^{4} \mathrm{CFU}^{*} / \mathrm{g}$ of dry soil

\begin{tabular}{|c|c|c|c|c|c|c|c|c|c|c|c|c|c|c|c|c|}
\hline 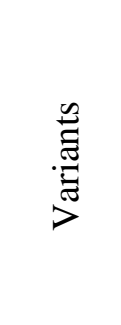 & 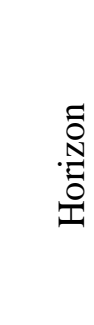 & 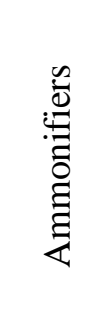 & 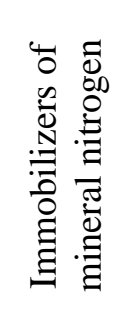 & 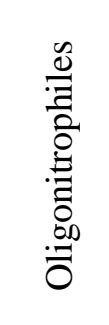 & 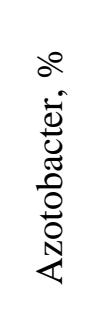 & 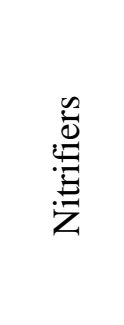 & 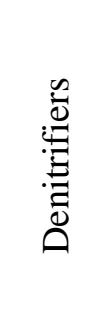 & $\begin{array}{l}\frac{n}{0} \\
\frac{0}{0} \\
0 \\
0 \\
0 \\
0 \\
0\end{array}$ & 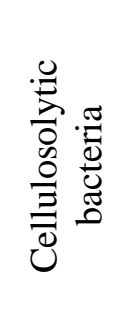 & 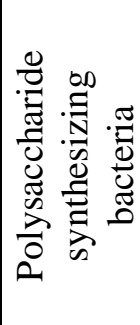 & 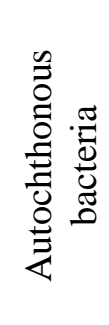 & 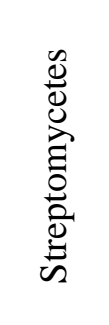 & 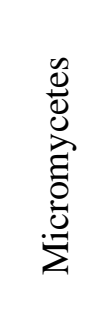 & 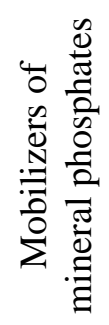 & $\mathrm{Kr}^{* * *}$ & 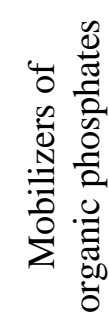 \\
\hline \multirow{3}{*}{ 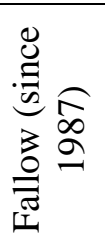 } & $\mathrm{He}$ & 4480 & 18840 & 17000 & 0 & 69,6 & 5400 & 20440 & 4960 & 1080 & 226,4 & 3440 & 9,36 & 23960 & 1,929 & 28700 \\
\hline & Ih & 186,0 & 730,5 & 736,7 & 2,0 & 0,551 & 263,1 & 714,7 & 177,3 & 25,6 & 3,29 & 41,9 & 0,59 & 645,6 & 0,886 & 806,4 \\
\hline & $\mathrm{Pi}$ & 0,996 & 0,563 & 1,99 & $-*$ & 0 & 1,656 & 2,49 & 0,984 & 0,056 & 0,002 & 0,003 & 0,024 & -* & $-*$ & 0,495 \\
\hline \multirow{3}{*}{ 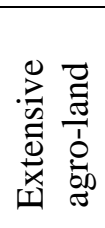 } & $\mathrm{He}$ & 2496 & 3120 & 5140 & 73,3 & 49,0 & 1400 & 6680 & 3440 & 365 & 325,6 & 1540 & 10,7 & 8510 & 0,973 & 5590 \\
\hline & Ih & 64,8 & 238,0 & 254,3 & 58,7 & 0,287 & 169,8 & 226,0 & 153,6 & 15,4 & 8,49 & 15,8 & 0,54 & 211,0 & 0,906 & 278,6 \\
\hline & $\mathrm{Pi}$ & 0,255 & 0,448 & 0,620 & -* & 0,001 & 1,574 & 0,945 & 0,254 & 0,028 & 0,062 & 0,004 & 0,012 & -* & -* & -* \\
\hline \multirow{3}{*}{ 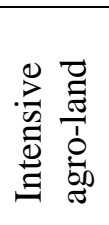 } & $\mathrm{He}$ & 4950 & 21580 & 5390 & 1,33 & 43,8 & 1105 & 8720 & 3880 & 194 & 294,2 & 2210 & 9,10 & 6900 & 1,144 & 7560 \\
\hline & Ih & 105,3 & 262,4 & 280,7 & 2,67 & 0,410 & 51,7 & 282,3 & 173,9 & 35,2 & 6,57 & 15,3 & 1,02 & 391,4 & 1,189 & 308,7 \\
\hline & $\mathrm{Pi}$ & 0,510 & 0,512 & 0,653 & -* & 0,002 & 0,029 & 0,548 & 0,168 & 0,022 & 0,051 & 0,010 & 0,005 & $-*$ & -* & -* \\
\hline $\mathrm{LSD}_{05}$ & $\mathrm{He}$ & 214,0 & 143,1 & 200,5 & 10,2 & 5,05 & 88,6 & 402,0 & 28,0 & 55,6 & 20,8 & 94,6 & 0,05 & 45,8 & 0,015 & 39,1 \\
\hline $\mathrm{LSD}_{05}$ & Ih & 12,3 & 30,1 & 25,3 & 0,50 & 0,090 & 15,5 & 44,2 & 5,14 & 8,05 & 0,90 & 1,00 & 0,04 & 20,1 & 0,018 & 18,7 \\
\hline $\mathrm{LSD}_{05}$ & $\mathrm{Pi}$ & 0,142 & 0,040 & 0,028 & & 0,0005 & 0,01 & 0,31 & 0,072 & 0,006 & 0,009 & 0,001 & 0,001 & $-*$ & $-*$ & $-*$ \\
\hline
\end{tabular}

Note. CFU* - colony forming unit, $\mathrm{Kr}^{* *}$ - coefficient of specific phosphoribilizing activity; -* - not determined 
Table 2. Probability of formation of microorganism colonies $\left(\lambda, h^{-1} \cdot 10^{-2}\right)$ and intensity indices of mineralization processes in gray forest soils of various uses

\begin{tabular}{|c|c|c|c|c|c|c|c|c|c|c|c|c|c|c|c|}
\hline \multicolumn{12}{|c|}{ Probability of formation of colonies of microorganisms } & \multirow[b]{2}{*}{ 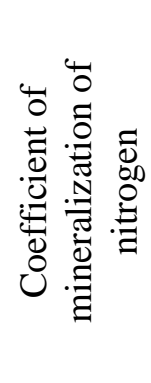 } & \multirow[b]{2}{*}{ 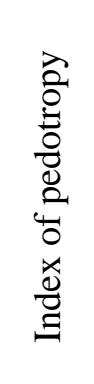 } & \multirow[b]{2}{*}{ 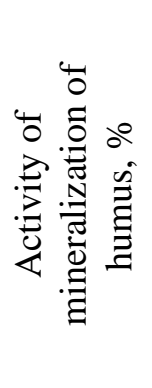 } & \multirow[b]{2}{*}{ 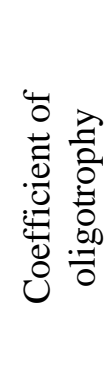 } \\
\hline 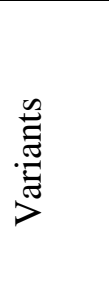 & 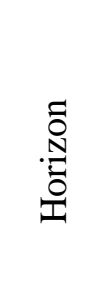 & 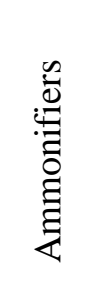 & 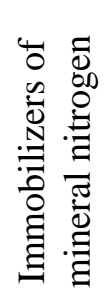 & 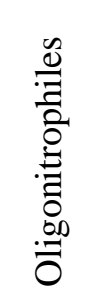 & 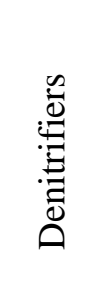 & $\begin{array}{l}n \\
\frac{a}{2} \\
0 \\
0 \\
0 \\
0 \\
0 \\
0\end{array}$ & 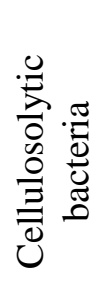 & 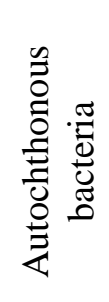 & 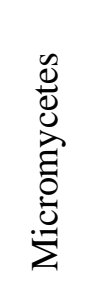 & 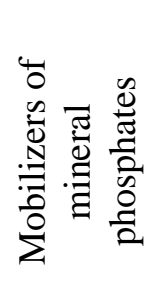 & 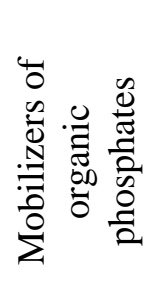 & & & & \\
\hline \multirow{3}{*}{ 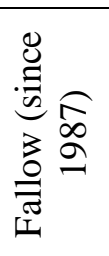 } & $\mathrm{He}$ & 3,20 & 4,10 & 1,10 & 0,21 & 1,84 & 3,81 & 0,80 & 5,71 & 4,30 & 4,40 & 4,21 & 4,56 & 11,1 & 3,79 \\
\hline & Ih & 1,30 & 2,61 & 0,72 & 0,08 & 0,81 & 4,40 & 0,71 & 1,00 & 2,21 & 3,82 & 3,93 & 3,84 & 12,8 & 3,96 \\
\hline & $\mathrm{Pi}$ & $-*$ & 90,0 & 2,63 & 9,90 & 1,12 & 1,72 & 0,80 & 3,74 & -* & 9,90 & 0,57 & 2,50 & 0,05 & 2,04 \\
\hline \multirow{3}{*}{ 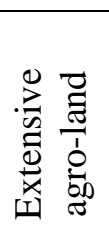 } & $\mathrm{He}$ & 2,90 & 2,50 & 1,90 & 0,004 & 0,80 & 2,11 & 0,81 & 6,20 & 2,81 & 5,11 & 1,25 & 2,67 & 48,7 & 2,06 \\
\hline & Ih & 1,61 & 3,01 & 1,10 & 0,81 & 1,23 & 3,30 & 0,50 & 3,31 & 3,02 & 4,62 & 3,67 & 3,50 & 37,5 & 3,92 \\
\hline & $\mathrm{Pi}$ & $-*$ & 10,1 & 1,95 & 0,92 & 1,50 & 2,30 & 1,10 & 6,50 & $-*$ & $-*$ & 1,76 & 3,70 & 6,60 & 2,43 \\
\hline \multirow{3}{*}{ 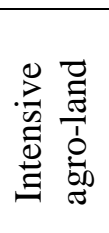 } & $\mathrm{He}$ & 0,50 & 1,21 & 2,00 & 12,5 & 2,11 & 3,44 & 0,94 & 5,80 & 2,50 & 1,63 & 4,36 & 1,76 & 33,7 & 1,83 \\
\hline & Ih & 6,51 & 3,71 & 2,51 & 0,23 & 2,80 & 3,32 & 0,93 & 4,21 & 4,41 & 4,50 & 2,49 & 2,68 & 23,3 & 2,67 \\
\hline & $\mathrm{Pi}$ & -* & 6,90 & 1,40 & 12,6 & 5,90 & 3,30 & 1,10 & 6,90 & -* & -* & 1,00 & 1,07 & 9,25 & 1,28 \\
\hline
\end{tabular}

Note. -* - not determined 
The data obtained by us on the more gradual decrease in the number of microorganisms in the layland soil, as compared with the agrarian soils, does not coincide with the data of T. H. Dobrovolska [4], according to which, a virgin (forest) soil is characterized by a sharp decrease in the number and variety of microorganisms in the soil profile compared with cultivated soils. According to our data, only the number of polysaccharide-synthesizing microorganisms, organic phosphates mobilizers and autochthonous microbiota decreases in depth of the profile from both agrocenoses (Table 1). Also, we had noted almost identical rates of decrease in the number of all studied variants of the use of soil microorganisms such as pedotrophs and oligonitrophils.

It is important to study the patterns of distribution of the micellar forms by the soil profile: the maximum rates of decrease in the number of micromycetes are characteristic for the profile of extensive agrocenosis, the minimum - for the intensive one. The rate of decrease in the number of streptomyces depends not only on the way of using the soil, but also from the horizon. It should also be taken into account the existence of spores and conidia in these groups of microorganisms, which can be transported with capillary water and remain in anabiotic state for an extended period, sprouting on digest media.

Nitrifiers are characterised by a sharp decrease in the number by layland profile (Table 1). As the microorganisms of this group belong to the strict aerobes, the marked feature indicates, first of all, the lack of oxygen content in the lower horizons of the layland profile. This is also confirmed by the maximum number of denitrifiers (anaerobes) in the layland Pi horizon.

The maximum amount of azotobacter is contained in the soil of extensive agrarian soil, in the soil of intensive agrarian soil it is present in small amounts, and it is absent in the layland soil. This pattern is confirmed by long-term observations. The study of the probability of formation of colonies has shown that the physiological state of microorganisms depends both on the horizon and on the way of using the soil (Table 2). Thus, the physiological and biochemical activity of the ammonifiers of the upper horizon and the extensive agrarian soil is higher compared with the activity of microorganisms of the Ih horizon, and vice versa is it lower in the intensive agrarian soil. Cellulolytics in the layland soil and extensive agrarian soil are also more active in Ih horizon, and in intensive agrarian soil, activity is the same in all studied horizons. Layland pedotrophs are more active in He horizon, and pedotrophs of agrarian soils - in the lower horizons. Thus, the physiological activity of microorganisms in the soil horizons depends on many factors, in particular on the intensity of the transport of substrates and restorers in the depths of the soil profile, the depth of penetration of the plant roots, the presence or absence of mechanical cultivation of the upper layers of the soil. Therefore, the physiological and 
biochemical activity of microorganisms with the deepening of the horizon of the existence of the corresponding group of microorganisms does not correlate linearly.

The analysis of factors and indices that give an opportunity to characterize the direction and intensity of microbiological processes shows that the degree of development of organic matter of the soil in the depth of the profile of layland and intensive agrarian soil is reduced by 82.4 and $64.4 \%$, respectively, and vice versa in the depth of the profile of extensive agrarian soil - increases by $38.6 \%$ (Table 2). At the same time, a pedotrophicity coefficient is observed in the illuvial-humus horizon. The oligotrophicity coefficient increases for all variants of the use of gray forest soil in the illuvial-humus horizon, and then decreases in the Ri horizon.

The factor of immobilization and mineralization of nitrogen from $\mathrm{He}$ horizon to $\mathrm{Ih}$ horizon gradually decreases in the depth of the profile of the layland and intensive agrarian soils. With the transition to Ri horizon, the factor of mineralization of nitrogen sharply decreases: in the layland 6.9 times, in intensive agrarian soil - 2.5 times compared with the Ih horizon. For extensive agrarian soil, the low intensity of mineralization processes in $\mathrm{He}$ horizon is characteristic.

The activity of mineralization of humus in the layland soil is minimal, in the extensive agrarian soil it is maximal. For all three variants of soil use, there is a clear tendency to decrease the activity of humus degradation down the profile. The agrochemical characteristics of the layland soil indicate that the soil of He horizon contains humus of $1.43 \%$, Ih horizon -0.41 , and Ri horizon $-0.18 \%$ [6]. That is, the content of humus between the horizons decreases by 3.49 and 7.94 times. The number of autochthonous microorganisms decreases at a significantly higher pace - by 68.8 and 113,200 times, respectively, while the physiological and biochemical activity of these microorganisms in different horizons of the layland soil remains almost identical. Consequently, the activity of decomposition of humus depends on many factors: the content of humus, the concentration of easily recovered substrates and macroelements, presence of which influences mineralization of humus substances, the availability of oxygen, the number of autochthonous microorganisms, their physiological and biochemical activity, and other factors.

Consequently, according to the results of the study, the following features are established.

1. Humus-accumulative, illuvial horizons and horizon transitional from the illuvial to the rock of the gray forest soil differ in the number and physiological and biochemical activity of the microorganisms of the studied ecological trophic groups and depend on the way of using the soil. Reduction of the number of microorganisms in the horizons of the layland compared with agrarian soils is slower, perhaps due to the existence of a more effective system of transportation of substrates and restorers down the profile on the layland soil. 
2. The degree of absorption of the organic matter of the layland soil and the intensive agrarian soil decreases from $\mathrm{He}$ horizon to $\mathrm{Ri}$ horizon by 82.4 and $64.4 \%$, respectively; pedotrophicity coefficient increases in the depth of the profile of extensive agrarian soil in Ih horizon and decreases in Ri horizon. The oligotrophicity factor increases in all variants of the use of soil in the illuvially-humus horizon.

3. The intensity of mineralization of nitrogen compounds from He horizon to Ih horizon gradually decreases in the depth of the profile of layland and intensive agrarian soil. Ri horizon is characterized by a sharp decrease in the intensity of mineralization of nitrogen compounds: in the layland - by 6.9 times, in intensive agrarian soil - by 2.5 times. For extensive agrarian soil, a low level of mineralization processes intensity is typical for He horizon.

The previously obtained data on the minimum activity of humus mineralization in all the horizons of the layland soil, the maximum - in the extensive agrarian soil, have been confirmed. Regardless of the type of soil use, there is a clear tendency to decrease in the activity of humus degradation down the profile. 
1. Распределение численности и биомассы микроорганизмов по профилям зональных типов почв / Л. М. Полянская, В.В.Гейдебрехт, А. Л. Степанов, Д. Г. Звягинцев // Почвоведение. - 1995. - № 3. - С. 322-328.

2. Особенности пространственного распределения и структуры микробных комплексов болотно-лесных екосистем / [А.В. Головченко, Л. М. Полянская, Т. Г. Добровольская и др.] // Почвоведение. - 1993. - № 10. - С. 77-90.

3. Головченко А. В. Структура бактериальных комплексов в заповедных ельниках / А. В. Головченко, Т. Г. Добровольская, И. Ю. Чернов // Почвоведение. - 1995. — № 9. C. 1121-1124.

4. Добровольская Т.Г. Бактериальное разнообразие целинных и пахотных почв Владимирской области / Т. Г. Добровольская, И. Ю. Чернов, С. М. Лукин // Почвоведение. — 2001. - №9. - C. 1092-1096.

5. Богоев В. М. Количественная оценка численности, биомассы и биологической активности почвенных микроорганизмов в экосистемах некорых природных зон : автореф. дис. ... канд. биол. наук : 03.00 .07 - микробиология / В. М. Богоев. - М.: Изд-во МГУ, 1981. - 25c.

6. Гамалєй В. І. Особливості процесів грунтоутворення на вилучених з обробітку землях / В. І. Гамалєй, С. Г. Корсун // Збірник наукових праць Інституту землеробства. К. : Нора Прінт. - 2003. - Вип. 4. - С. 22-25.

7. Теппер Е. 3. Практикум по микробиологии / Е. З. Теппер, В. К. Шильникова, Г. И. Переверзєва. - М. : Дрофа. - 2004. - 256 с.

8. Мишустин Е. Н. Успехи разработки принципов микробиологического диагностирования состояния почв / Е. Н. Мишустин, Е. В. Рунов // Успехи современной биологии. - 1957. - Т. 44, № 2. - С. 256-267.

9. Никитин Д. И. Процессы самоочищения окружающей среды и паразиты растений / Д. И. Никитин, В. С. Никитина. - М. : Наука. - 1978. - 205 с.

10. Демкина Т. С. Микробиологические процессы в почвах при различных уровнях интенсификации земледелия / Т. С. Демкина, Б. Н. Золотарева // Микробиологические процессы в почвах и урожайность сельскохозяйственных культур. - Вильнюс. - 1986. - C. 101-103.

11. Кожевин П. А. Определение состояния бактерий в грунте / П. А. Кожевин, Л. С. Кожевина, И. Н. Болотина // Доклады АН СССР. - 1987. - Т. 297, № 5. C. 1247-1249. 


\section{ПРОСТРАНСТВЕННАЯ СТРУКТУРА БАКТЕРИАЛЬНЫХ ЦЕНОЗОВ СЕРОЙ ЛЕСНОЙ ПОЧВЫ ПРИ ЕЕ РАЗНЫХ УСЛОВИЯХ ИСПОЛЬЗОВАНИИ}

\section{И.М. Малиновская}

\author{
ННЦ «Институт земледелия НААН», \\ п.г.т. Чабаны, Киевская обл.
}

В условиях стационарного опыта и на участках залежи изучали состояние микробиоченозов горизонтов серой лесной почвы: гумусово-аккумулятивного (0-29см), иллювиального (30-50см), переходного от иллювиального горизонта до породы (92110 см). Установлено, что с глубиной по профилю почвы изменяется численность $u$ физиолого-биохимическая активность микроорганизмов исследованных экологотрофических групп, интенсивность $и$ направленность минерализачионных прочессов. Характер и масштабы таких изменений зависят от способа использования nочвы.

Ключевые слова: бактериальные ценозы, горизонты почвенного профиля, серая лесная почва, эколого-трофические группь, минерализация

\section{ПРОСТОРОВА СТРУКТУРА БАКТЕРІАЛЬНИХ ЦЕНОЗІВ СІРОГО ЛІСОВОГО ГРУНТУ ЗА РІЗНИХ УМОВ ВИКОРИСТАННЯ}

\section{І.М. Малиновська}
ННЦ «Інститут землеробства НААН», с.м.т. Чабани, Київська обл.

В умовах стаціонарного досліду $i$ на перелогових ділянках досліджували стан мікробіоченозів горизонтів сірого лісового трунту: гумусно-акумулятивного (0-29см), ілювіального (30-50см), перехідного від ілювіального горизонту до породи (92-110 см). Встановлено, щзо з глибиною у профілі трунту змінюється чисельність і фізіолого-біохімічна активність мікроорганізмів досліджених еколого-трофічних груп, напруженість $i$ спрямованість мінералізаціийних процесів. Особливості $i$ масштаби таких змін залежать від способу використання трунту.

Ключові слова: бактеріальні цеенози, горизонти трунтового профілю, сірий лісовий грунт, еколого-трофічні групи мікроорганізмів, мінералізація. 